\title{
Why do fishermen discard? Distribution and quantification of the causes of discards in the Southern Bay of Biscay passive gear fisheries
}

\author{
G. Morandeau ${ }^{a, *}$, C. Macher ${ }^{b}$, F. Sanchez ${ }^{a}$, N. Bru ${ }^{c}$, L. Fauconnet ${ }^{d}$, N. Caill-Milly ${ }^{a}$ \\ a Ifremer Laboratoire Ressources Halieutiques Aquitaine RBE HGS, UFR Côte Basque, FED MIRA 4155, \\ F 64600 Anglet, France \\ ${ }^{\mathrm{b}}$ Ifremer UMR AMURE, Unité d'Économie Marine RBE EM, Centre Bretagne, Plouzané, France \\ ${ }^{c}$ Laboratoire de Mathématiques et de leurs Applications de Pau, UMR CNRS 5142, FED 4155 - MIRA, , Pau, \\ France \\ d Ifremer Unité Écologie et Modèles pour l'Halieutique Marine RBE EMH, Centre Atlantique, Nantes, France \\ *: Corresponding author : Gilles Morandeau, tel.: +33229008597 ; fax: +33229008552 ; \\ email address : gilles.morandeau@ifremer.fr
}

\begin{abstract}
:
In the context of the Common Fisheries Policy reform, the need for decreasing discards has been highlighted in discussions on the implementation of a discard ban. While most of the research has focused on the quantification of discards by species and métier, identification and quantification of the causes of discards have received little attention. This study presents the results of on-board surveys conducted in the Southern Bay of Biscay fleets of netters and longliners. A large variability of discards was observed. It is also shown that in these passive gear fisheries the main reasons for discarding put forward by fishermen are, firstly, market-related and, secondly, quality-related; discards related to the application of regulations are minor. The results therefore illustrate that decisions to discard can also occur in highly selective fisheries because of economic constraint and the results also show that a part is discarded alive.
\end{abstract}

\section{Highlights}

Reasons for discarding from passive gears in the Southern Bay of Biscay are examined. Large variability of discarding between métier and over time was observed. Market causes mainly explain discarding reasons for netters and longliners. Scavengers action participates to discards on passive gears in decreasing quality.

Keywords: Discards ; On-board surveys ; Interviews ; Causes of discards ; Nets ; Bottom longline 


\section{Introduction}

During the World Summit on Sustainable Development in Johannesburg (South Africa 26th August4th September 2002), attending heads of State and Government recommended maintaining and restoring fish stocks to levels that achieve Maximum Sustainable Yield, with the aim of reaching this important objective for depleted stocks by 2015 [1]. Discards are one aspect of overfishing. Discard is the portion of the catch returned to the sea. The discard rate is the ratio between discard and total catches, it may be computed for individual species or combined groups of species [2].

Today, the Common Fisheries Policy (CFP) of the European Union is undergoing reform; decreasing discards has been put forward as being one of the main challenges of this reform. Moreover discards have been presented as one of the reasons why stocks have not recovered as expected. Implementation of a discard ban is under discussion within the CFP reform. In February 2013 the European Parliament voted on the principle of the prohibition of discarding catches. 
Recently, the European Commission and the European Parliament have been in agreement on the proportion of discards obligatorily landed; the application of this vote will soon come into effect. Elsewhere, some countries such as Norway have chosen to partially ban discards, and in the case of Namibia bycatch from trawl fishery is landed for conversion to fish meal $[3,4]$.

Estimation of discarded quantity is difficult and somewhat controversial, especially on a large scale. Moreover, an inaccurate estimation may cripple efforts made elsewhere to reduce discarding by casting doubt on that estimation [3]. First estimations of worldwide discards in commercial fisheries made by Alverson et al [5] were between 20 million tons to 27 million tons of discards per year, the equivalent of about one quarter of total catches. In 2005 Kelleher [2], using another method, revised these estimations downwards and stated that discards were about 7 million tons per year, that is $8 \%$ of the total catches in weight, with high variability between fisheries. Estimation per fishery shows that the discard rate can be much higher, particularly in demersal fisheries (discard rate can reach up to $80 \%$ in some fisheries).

Discarding of an undersized or damaged individual in a commercial fish catch limits future opportunities and entails loss of income and food resources [6, 4]. From an economic perspective, discarding practices by fishermen are a loss for themselves as well as for the whole society $[6,7]$. However negative indirect effects have also been simulated in the case of shrimp trawl fishery in Gulf of Mexico by Walters et al [8]. In this case, simulated discards reduction led to a decrease on the productivity of some valued species, by encouraging the recovery of their predators such as catfishes. Furthermore discards survival can be non-negligible for some species and discarding could also have positive indirect impacts through supply and market price. This issue raises several contradictions. In spite of the phenomenon of wasted food observed around the world [9], the ethical and the moral dimension is often put forward by some NGOs who consider discards as food losses.

Analyses of the bio-economic impacts of improving selectivity measures, for example, in the case of the Bay of Biscay fisheries, show benefits expected from decreasing discards [10] and for non marketed species. Discarding implies additional mortality and impacts the ecosystem [11]. It can have ecological impacts on food webs by diverting a part of the energetic flow intended for predators in direction of the scavengers $[12,13]$. In the North Sea populations of scavengers have grown, while demersal species diversity has declined [11]. Moreover, it is well known that discards are very attractive to some bird populations and contribute to their diet $[14,15,16]$.

Pascoe [6] highlights low landing values and also the minimum landing size as the main reasons for discarding. However, observational studies of the causes of discards have remained very scarce [17], whereas impact assessment of a discard ban requires good knowledge of fishermen's behaviour and practices. Besides this, analyses of the causes of discarding and estimation of discards generally focus on fleets using mainly active gears and operating in multi-species ecosystems. Thus, most of the scientific approaches have focused on bottom trawl fisheries. The relationship between the mesh size of this gear and discards of juveniles has been well demonstrated [18, 19], and the sizes of discards have been observed on board professional vessels [19]. Other studies analyzed discards as a result of physical damage, particularly in the case of non-target species [20]. The assessment of discards has also been studied by using a predictive model [21], and discards are increasingly incorporated into stock assessment [22]. The reasons for discarding were also ascertained occasionally from fishermen at sea mainly on trawlers, and also with fisher self-sampling [23]. Discards are highly variable from one boat to another and depend on the season [17]. They are also the result of personal, economic [24-30] or legal considerations.

This study explores the reasons for discarding from the fishermen's perspective. It focuses on qualification and quantification of the causes of discards in the case of passive gears. The document presents the results of on-board surveys conducted in the Southern Bay of Biscay among netter and 
longliner fleets operating around the Capbreton Canyon, and discusses results in comparison with the netter and longliner fleets population operating in the Bay of Biscay.

\section{Material and methods}

\subsection{Study area and fishing activity}

The study area is the southern part of the Bay of Biscay continental margin, mainly along the Landes Plateau. The continental Aquitaine slope is deeply incised by the Capbreton Canyon and is influenced by the plume of major rivers: the Adour and Gironde Rivers. They contribute to successful reproduction, feeding and nursery functions for many species [31-34]. The canyon enhances the concentration of mature hake [35] and the presence of species which live in deep areas.

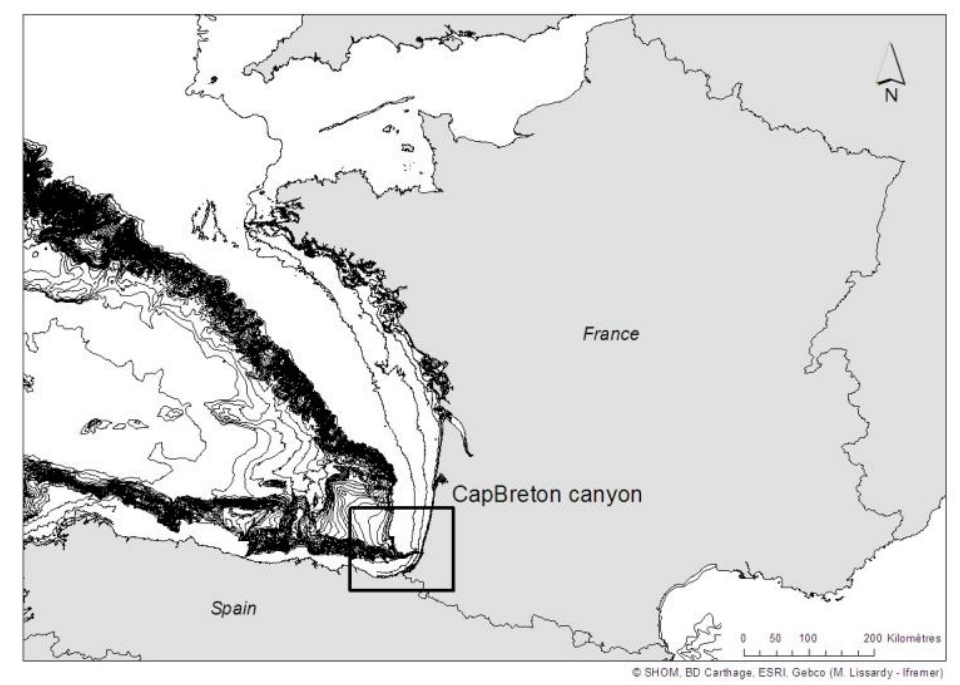

Fig. 1. Study area of LOUPE Program.

The Southern Bay of Biscay is mainly characterized by pelagic fisheries, such as purse seiners, baitboaters and pelagic trawlers, and demersal fisheries, such as netters, bottom trawlers, longliners and potters. The fleets are mostly coastal and often polyvalent; gillnetters, bottom longliners and trawlers are the main métiers. The main demersal species targeted are European hake (Merluccius merluccius), monkfish (Lophius piscatorius and L. budegassa), European sea bass (Dicentrarchus labrax), common sole (Solea solea), turbot (Scophthalmus maximus) and Sparidae [36].

2.2. Descriptions of the studied métiers

In this study, only passive gears are considered: nets and longlines.

The longlines used in the hake fishery are semi-pelagic and are deployed on the edge of the Capbreton Canyon. It is an emblematic and major métier benefiting from a particular regulation as they take advantage of a prohibition of net and trawl fishing on their fishing grounds [37]. Between 8 and 14 costal boats practice this métier during the year (Table 1), and the fleet characteristics are homogeneous. Boats lay between 1,200 and 1,800 hooks per day, baited with frozen pilchard (Sardina pilchardus). Two or three men are on board these vessels. Fishing is mostly practiced in spring and summer but a small number of vessels work all year. Generally, trips last between ten and twelve hours; longline is set before sunrise and retrieved three or four hours later. Hake is the main targeted species; other targets are pollack (Pollachius pollachius), red sea bream (Pagellus bogaraveo) and conger (Conger conger). 
Table 1. Main characteristics of the two métiers practiced and observed in the Capbreton area (statistical rectangle scale 16E8) from the database Fisheries Information System (population, year 2012) and from LOUPE program (sample).

\begin{tabular}{lcccc}
\hline Characteristics & \multicolumn{2}{c}{ Métier longline } & \multicolumn{2}{c}{ Métier nets } \\
& $\begin{array}{c}\text { Population } \\
(\mathrm{SD})\end{array}$ & $\begin{array}{c}\text { Sample } \\
\text { (SD) }\end{array}$ & Population & Sample \\
& 14 & 4 & 34 & 5 \\
\hline Number of vessels & $10.5(0.75)$ & $11(0.56)$ & $10.7(2.48)$ & $11.2(1.38)$ \\
Mean length (m) & $2.5(0.53)$ & $2.6(0.5)$ & $3(1.44)$ & $2.8(0.89)$ \\
Mean crew number & $12(4.72)$ & $10(0.97)$ & $12(16.32)$ & $9(1.77)$ \\
Mean fishing trip duration (h) & 4 & 4 & 24 & 23 \\
$\begin{array}{l}\text { Mean fishing operation } \\
\text { duration (h) }\end{array}$ & & & &
\end{tabular}

Netting is a major métier in terms of vessels involved and the number of trips $[36,38]$. Crew composition varies and depends on boat length (from one to four men on average). This métier is practiced by 30 to 35 boats all year round, but fleet characteristics are less homogeneous than in the case of longliners (Table 1). The strategy of these netters operating in the coastal area is based on the use of several types of nets (gillnets and trammel nets) targeting several species, often sold directly to consumers on the docks. Gillnets, consisting of a single mesh, target hake, sea bass and sea bream species (Diplodus spp, Sparus aurata, Litognathus mormyrus), while the trammel nets (three meshes) are used to capture benthic fish, such as common sole, monkfish (Lophius spp), turbot and brill (Scophthalmus rhombus). Generally, trips last less than twelve hours for coastal netters (less than $15 \mathrm{~m}$ ), which predominate in the sector, and a few days for large netters. On average, the coastal vessels set 6000 to $8000 \mathrm{~m}$. nets daily. This number is much higher for offshore netters. Usually nets are set on the seabed and retrieved the following day, but when red mullet (Mullus surmuletus) and European hake are targeted, nets are retrieved four or five hours later. Species such as the common sole, gilthead sea bream, meager, sea bass and hake are caught seasonally. Other species are caught more regularly, such as Atlantic bonito (Sarda sarda).

2.3 Observations of discards and causes of discards on board commercial fishing vessels

Observations and interviews made on board commercial vessels were used to qualify and quantify causes of discards. Data were collected from the regional program LOUPE (Observation of the habitat and associated communities in the context of the fisheries of the Capbreton Canyon). It consisted in the observations of two métiers practiced around the canyon. The observations were carried out between July 2011 and April 2013 on coastal boats.

The program was based on observations of the fishing métiers and strategies. The objective of the LOUPE program was to collect different data at sea (on coastal boats): fishing effort and catches, discarding reasons, costs and incomes by fishing trips, crew composition, sharing turnover and also undersea pictures. The quantitative and qualitative observation of the discards was not based on a stratified sampling plan but relied on opportunity. 
The goal was also to develop knowledge of the fishing pressure and impact exerted on marine ecosystems, and to examine how observational data at sea may contribute to the observation of others marine species including mammals, birds and benthos.

During the fishing trips, all fish and commercial invertebrates were identified, counted and measured; individual weights were registered by direct weighing or determined using length-weight relationships; data on the fishing trip and fishing operations such as geographical positions, date, fishing time, type of gear and its characteristics, target species and fishing depth were collected as well. The observer also registered whether fish were released alive. Some economic information, such as costs and revenues of the fishing trip, the fishermen's share in the catch, and selling place, was also collected on board by simply asking the fishermen.

Table 2. Registration criteria for discards.

\begin{tabular}{clll}
\hline Preference & Issue Class & Denomination & Issue Acronym \\
\hline $\mathbf{1}$ & Regulation & No quota available & NQ \\
& & Protected species & PS \\
& & Under minimum legal size & LS \\
& Quality & $\begin{array}{l}\text { Poor quality or quality } \\
\text { considered as being } \\
\text { insufficient }\end{array}$ & PQ \\
& & $\begin{array}{l}\text { Degraded quality because } \\
\text { scavenging or predation }\end{array}$ & SP \\
& & $\begin{array}{l}\text { Female carrying eggs } \\
\text { (crustaceans) }\end{array}$ & FR \\
& Absence of a market or no & NM \\
& commercial opportunity & \\
& & Unattractive price & UP \\
& & $\begin{array}{l}\text { Inadequate size for the usual } \\
\text { market }\end{array}$ & IS \\
& Destroyed or unsorted & DS \\
& & &
\end{tabular}

Fishermen were also questioned during the trip about the reasons for discarding a part of the catch. Four categories of reasons for discarding have been determined from the literature review and from fishermen's responses: regulations, market, quality and uses (Table 2). Regulatory constraints that can result in discards are detailed in the appendix. But these constraints are not the direct cause of discards. From the fishermen's point of view "Absence of a market or no commercial opportunity" can mean: "there is no market; it does not exist" and also "the market is occupied for now by different concurrent métiers, so we cannot access it in these conditions, and the price is not attractive". In case of doubt, the criterion adopted by observers was generally "unattractive price".

In the case of a fish which meets several criteria at the same time, the classification took place in the order of preference shown in Table 2. For example, an individual fish of Poor Quality (PQ) and 
out of the Legal Size (LS) is classified LS but not PQ, because for fishermen, regulatory constraints prevail over those of quality, which in turn prevail over those of markets. If fishermen are never sure of the final price when selling a good quality fish, they are absolutely convinced that a poor quality fish will have little or no value. Regarding regulation, they prefer to abide by it even if sometimes they do not understand its purposes.

\subsection{Data analysis}

Description of the conditions in which discards occurred was undertaken using classical descriptors, both globally and for each of the considered métiers. Significant differences among the obtained values were in this case tested with Chi-2 tests (using a type I error rate at 0.05 ). Discard proportions per fishing trip and fishing operation were calculated in number for each métier.

Focusing on the 9 main discarded species, a Multiple Correspondence Analysis (MCA) was applied to these species, the causes of discards, the place of sale and the type of gears in order to highlight some associations among them and to discuss about the main reasons which generated discards.

Data on catches (discards and landings) collected on board netters and longliners inferior to $15 \mathrm{~m}$ by the French national observer program in 2011 (in the whole Bay of Biscay, i.e. ICES divisions VIIIa and VIIIb) conducted within the DCF by Ifremer/Fisheries Information System/DPMA are registered in the Harmonie database [39]. They were used to compare some causes of discard with observations undertaken in the LOUPE program: directly for regulation reasons (protected species and minimum landing size); indirectly for market reasons in considering the species composition and seasonal variability of discards.

\section{Results}

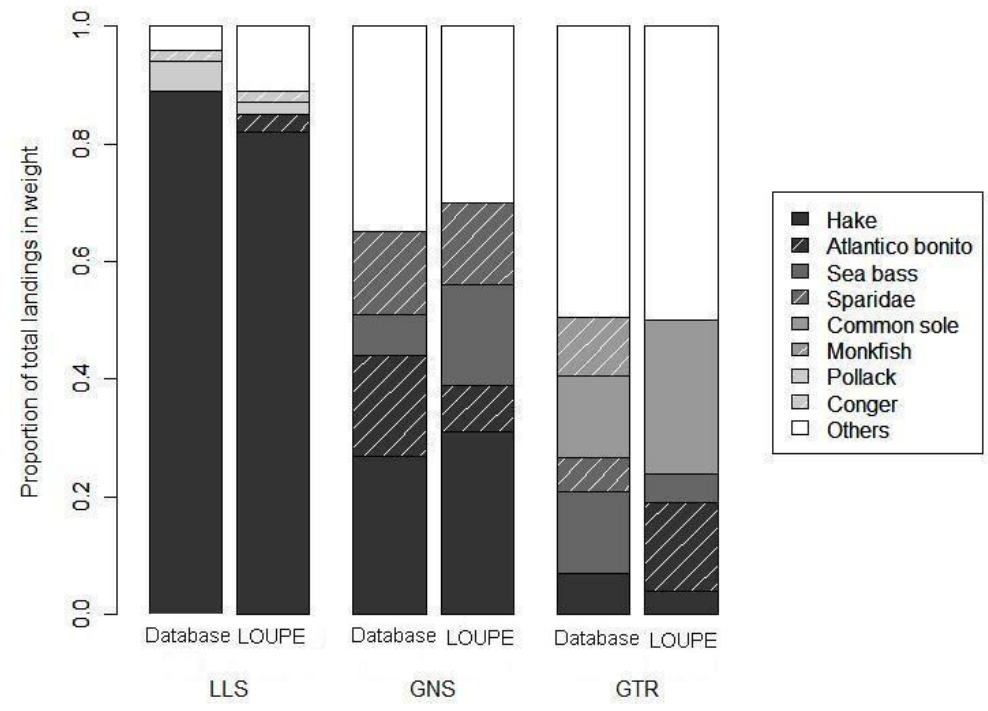

Fig.2. Main species landed of two métiers practiced in the Capbreton area (statistical rectangle scale 16E8) from the database Fisheries Information System (year 2012) and from LOUPE program.

During the LOUPE program, 9 different vessels were observed: four longliners and five netters, with 24 longliner operations and 27 fishing operations involving the netters. These observations at sea represent: $6 \%$ of longline fishing operations and $29 \%$ of this type of vessel operating in this area (reported in the database Fishing Information System on the statistic rectangle scale). In the same 
way, concerning the netters, observations represented $1 \%$ of netters' operations and $16 \%$ of fleets registered in the database. Depending on the gear used, the main targeted species were hake, Atlantic bonito, sea bass, common sole and Sparidae for netters, and mainly hake, pollack and conger for longliners (Fig.2).

In all métiers considered (on boats observed), discards represented $45 \%$ and $20 \%$ of the total catches in number and in weight respectively. However, differences were observed between métiers; trammel net generated a high proportion of discards in number $(2257$, i.e. $70 \%)$, whereas for gillnet and longline levels of discards respectively comprised between $25 \%$ (488) and $30 \%(780)$ of individuals caught (Fig. 3a). In weight (Fig. 3b), the trammel net generated as many discards 53\% $(484 \mathrm{~kg})$ as landings $47 \%(421 \mathrm{~kg})$, while gillnet and longline produced few discards, respectively $11 \%(124 \mathrm{~kg})$ and $12 \%(266 \mathrm{~kg})$.
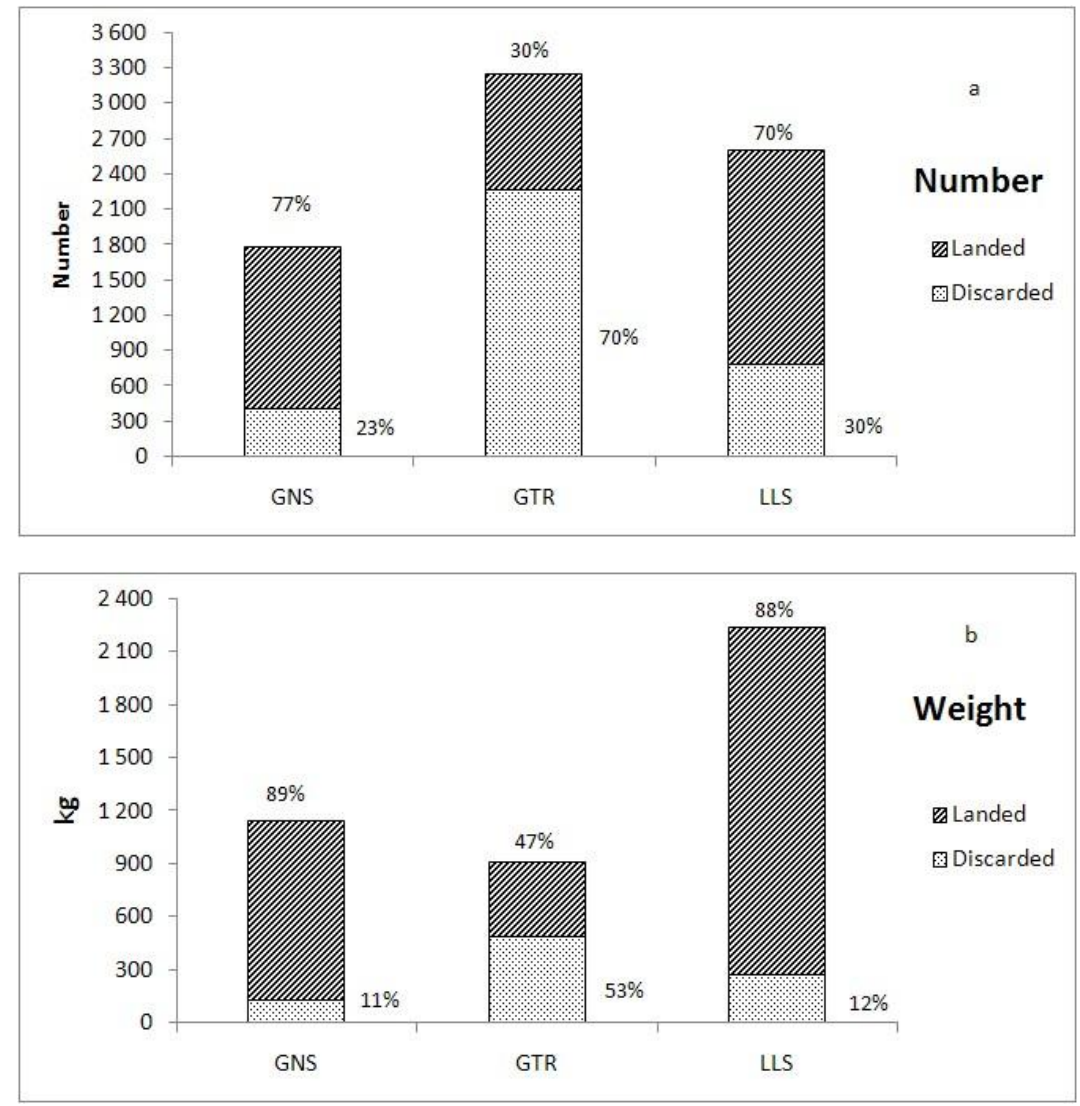

Fig. 3. The relative contribution of discarded and landed catches by gear (GNS, gillnetters; GTR, trammel netters; LLS, bottom longliners).

During the 51 observed operations of the LOUPE program, 64 species have been identified as non-valuated catches (including seven quota species). Among these, the main species (representing more than $80 \%$ of the total discards expressed in number) were: Atlantic mackerel, blue whiting (Micromesistius poutassou), pilchard, horse mackerel (Trachurus trachurus), pout whiting (Trisopterus luscus) and black-mouthed dogfish (Galeus melastomus) (Fig.4). 


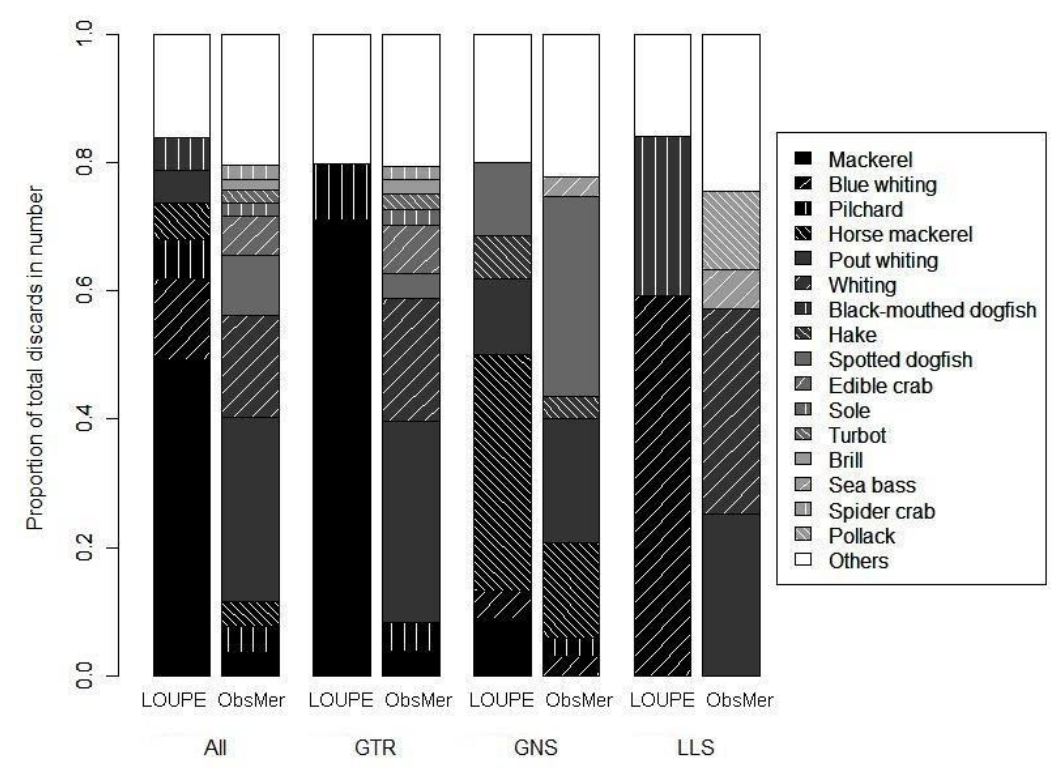

Fig.4. Distribution of species or groups of species contributing to $80 \%$ of the discards (in number) all gears combined and per gear (from LOUPE program and ObsMer program)

Two species were predominately discarded for longline (blue whiting and black-mouthed dogfish), but $44 \%$ of the discarded individuals were still alive when returned to sea. Between two and six species mainly contribute to discards from net fisheries, according to the type of net used. For trammel net, those species were the mackerels and pilchard; for gillnet, it was horse mackerel, pout whiting, spotted dogfish (Scyliorhinus canicula), mackerel, hake and blue whiting (Fig. 4). For netters, a small part of discards were alive $(3 \%)$.

In the Bay of Biscay, for longliner and netter fleets, according to the ObsMer program, species contributing to discards are more variable and also dependent on the gear used. Thus, spotted dogfish, whiting, pout whiting and crabs are the main species which are discarded for these gears.

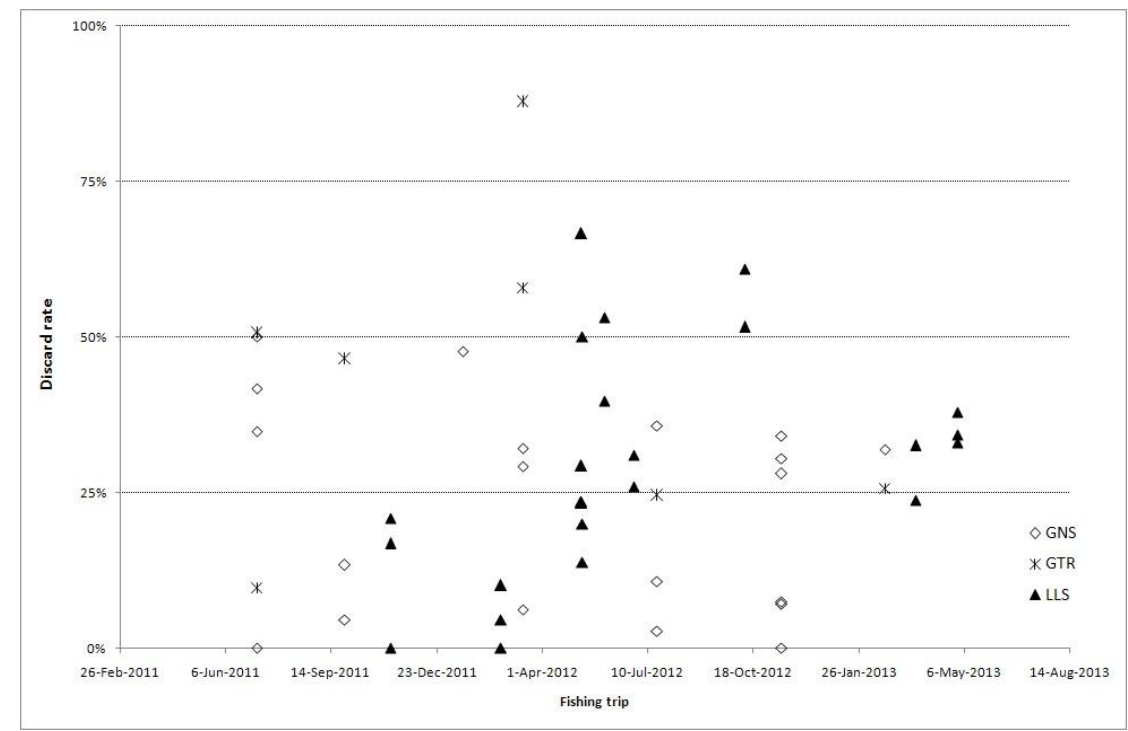

Fig. 5. Plot of discard rates aggregated across species and gear types. Each point corresponds to a fishing operation. 
Discard rates per fishing trip were calculated for each métier and refer to the discards in number (Fig.5). The variability of discard rates across trips was high. For longline (LLS), discard rates ranged from $0 \%$ to $67 \%$ among the fishing operations. For gillnet (GNS) and trammel net (GTR), the values ranged from $0 \%$ to $50 \%$ and from $10 \%$ to $88 \%$ respectively.

Table 3. Distribution of discards (in number) according to criteria and métiers.

\begin{tabular}{lllll}
\hline Criteria & Isue Acronym & GNS & GTR & LLS \\
\hline Market & IS & $21 \%$ & $4 \%$ & $5 \%$ \\
& NM & $30 \%$ & $4 \%$ & $61 \%$ \\
Quality & UP & $10 \%$ & $76 \%$ & $3 \%$ \\
& FR & - & $<0.1 \%$ & - \\
Regulation & LQ & $19 \%$ & $7 \%$ & $0.1 \%$ \\
& SP & $15 \%$ & $6 \%$ & $29 \%$ \\
Uses & NQ & $3 \%$ & $3 \%$ & $1 \%$ \\
\hline
\end{tabular}

Regarding discarding reasons, fishermen's strategies appeared to be driven by market considerations in these fisheries, since the three related criteria, i.e. "absence of a market or no commercial opportunity", "unattractive price" and "inadequate size for the usual market", concerned more than $61 \%$ of discards (Table 3), with differences between the three métiers considered. For trammel nets "unattractive price" dominated $(76 \%)$, whereas "absence of a market or no commercial opportunity" was more important for longliners $(61 \%)$, and the distribution among these three criteria was more balanced for gillnetters (Table 3). Reasons related to regulations were not uncommon, but were minor $(2.5 \%)$; the "out of minimum legal size" criterion represented $2 \%$ of the observations of all métiers considered. In comparison, on the scale of the whole Bay of Biscay netter and longliner fleets, undersize individuals (in number) represented larger proportions of the total discards: $7 \%$ for gillnetters, $13 \%$ for trammel netters and $34 \%$ for longliners. The catch of protected species was very rare (less than $1 \%$ of total catch in both number and weight) for all gears in both the Southern Bay of Biscay and the whole Bay of Biscay. Reasons relating to poor quality were equally important; they represented $13 \%$ to $34 \%$ of discards (according to the métier), with a variable part (from $6 \%$ for trammel net to $29 \%$ for longline) due to the action of either scavengers regularly observed on board, such as Nassarius reticulatus, Charonia lampas, or crustaceans like amphipods or Polybius henslowii. "Opportunistic predators", such as hake preying upon blue whiting, for example, or cephalopods upon tunas, also contribute to bad fish quality. In the whole Bay of Biscay no significant relationship (Fig. 6) was found between discards and soak time for the netters inferior to $15 \mathrm{~m}$ and longliners, neither for fragile species such as hake, nor for all species combined. 


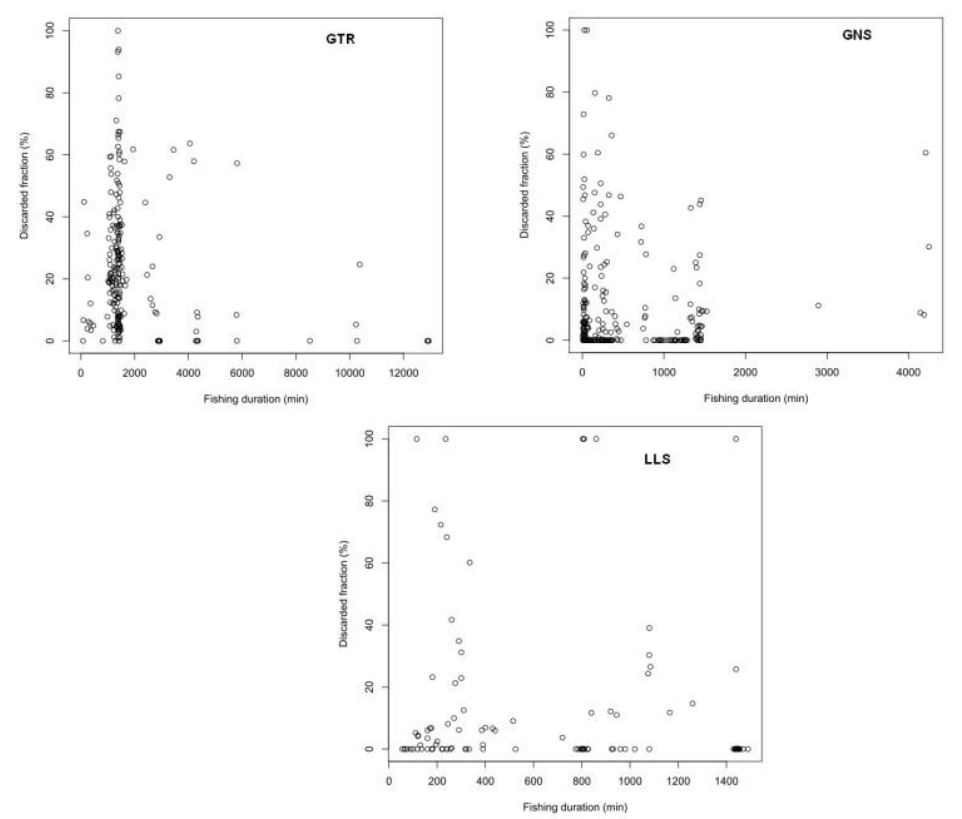

Fig. 6. Relationship between discard rate and fishing duration for the netters inferior to $15 \mathrm{~m}$ and longliners in the whole Bay of Biscay (source: FIS Database).

An MCA (Fig.7) was performed on the data table obtained from the LOUPE sampling program, containing 3,002 discards (each statistical unit is an individual discarded fish) associated with four criteria: species, discarding reasons, gear and selling place. Only major species were selected. The variance explained by each of the two axes was: axis $1=18.29 \%$ and axis $2=14.32 \%$. Associations between the places of sale (auction sale in fish market, directly to consumers, or both places), the different species and the gears used highlight the occurrence of the discards associated with these different criteria. An ascending hierarchical classification (with Ward's criterion) of the first two principal components from the MCA shows three groups. 


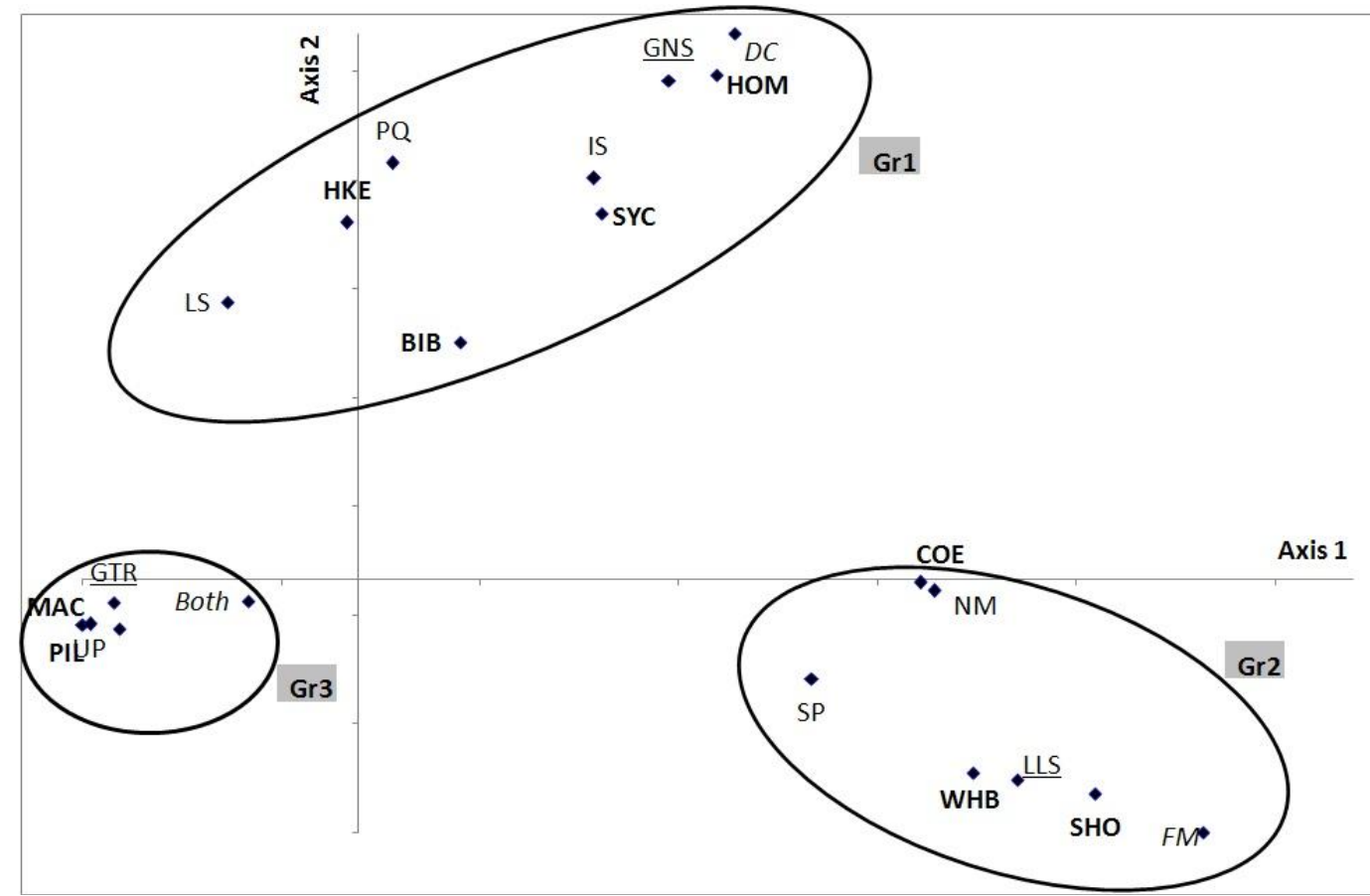

Fig. 7. Multiple Correspondence Analysis: Representation of categories using the two first factorial axis.

Species: MAC Atlantic mackerel; PIL European pilchard; WHB Blue whiting; COE European conger; BIB Pout whiting; HOM Horse mackerel; SYC Spotted dogfish; SHO Black-mouthed dogfish; HKE European hake.

Selling places: FM, Fish Market; DC: Directly to Consumers; Both places

Gears: GTR: trammel net; LLS: longlines; GNS: gillnets

Criteria : PS Protected species ; LS Under minimum legal size, PQ Poor quality or quality considered as being insufficient, SP Degraded quality because of scavenging or predation; UP Unattractive

Price; NM Absence of a Market or no commercial opportunity; IS Inadequate size for usual market.

The first group (Gp1): gillnetters mainly selling directly to consumers. Their discards consist of horse mackerel, spotted dogfish and hake, which are associated with poor quality, inadequate size and also with being under minimum legal size.

The second group (Gp2): longliners mainly selling to fish markets. Their discards, predominated by three species, blue whiting, European conger and black mouthed dogfish, are generally linked to scavenging or predation, and absence of market or no commercial opportunity.

The third group (Gp3): trammel netters selling in both places. Their discards, mainly composed of Atlantic mackerel and European pilchard, are usually related to unattractive price.

\section{Discussion}

For these two métiers, market considerations are the main reasons for discarding, and they are dependent on each fisherman and on his market. In this respect, economic issues are often cited in the literature $[2,3,4,6,17]$ as reasons for the discards. The observations and interviews conducted at sea during those fishing trips confirm and clarify the importance of these criteria for longliners and gillnetters in the southern Bay of Biscay. Thus, more than $83 \%$ of the discarded number is related to market issues $(56 \%$ for "unattractive price" and $21 \%$ due to "absence of a market or no commercial opportunity"), i.e. to the expected cost benefits of landing as opposed to discarding.

During the LOUPE program, two to six species contributed to $80 \%$ of discards for vessels observed, while in the whole Bay of Biscay it was seven to eight species, depending on gear only (cf. 
Fig. 4). These differences around discarded species compositions can also be explained by fishermen's behavior and by the biology (spatial and seasonal repartition of species). Dubé et al [40] show significant regional differences (according to French maritime façades) and also differences related to the respective métiers.

In southern Portugal, in the same way as in the LOUPE project, it was observed on hake bottom longliners [41] that Galeus melastomus, Micromesistius poutassou and Scyliorhinus canicula are discarded. In the study area (Southern Bay of Biscay), for the two last species, selling directly to the consumer can contribute to better sorting and less discard because fishermen consider that they have customers for those species. Thus, two boats chose direct sale, while others did not, and sold by auction instead.

Atlantic mackerel was often discarded by netters for market reasons. During springtime this species is also targeted by pelagic trawls. Their landed quantity is very significant, causing a market glut and low prices for all the other métiers practiced in this area. On the scale of the whole Bay of Biscay in 2011 the highest discarded fraction of mackerel was also observed in spring for trammel netters $(84 \%)$, but in summer for gillnetters $(17 \%)$. However, measured over a year, mackerel is not the main discarded species, in contrast to the LOUPE vessels.

Benoit and Allard [42] highlighted that collecting data concerning discards on board vessels may be biased because fishermen can change their attitude when fishing with an observer on board. Lart [23] therefore compared the results of two methods of data collection: one with an observer, the other from random sampling done by the fishermen themselves; he did not notice significant differences in the sorting behavior. During the trip observed for this study, we assumed that fishermen worked as usual, independently of the scientific observers (which are not sworn in and have no policing power), when sorting. However, sometimes they asked the observers to dispel their doubts about a particular protected species regulation or a minimum legal size.

Sampling was not constructed so that it is representative of métiers; it was a convenience sample of catches. This is not a probabilistic sampling protocol and therefore representativeness is not guaranteed statistically. However, the goal of this study was not to extrapolate possible results, but only to highlight some behavior. Regarding results observed in the study, vessels practicing longline are more homogeneous because their length, their crew composition and the fishing trip duration are similar (Table 1). Concerning their catches (from LOUPE), the share of each species (hake, pollack and conger) is very close to what was observed in the Fisheries Information System database (Fig.2). Concerning netters, two types of fleet must be considered: one practicing inside national water (they were observed in the LOUPE program) and others operating in offshore areas and targeting other species, for example monkfish (vessels not observed). With too few observations ( $1 \%$ of operations and $16 \%$ of total boats operating here), the sampling rate is too low to hope that the results of the study are representative of the total fleet operating in the rectangle 16E8. In all cases, fishermen's motivations, seasonality and the state of the market can change part of the discard. The assessment of representativeness was not the objective of the LOUPE program; more samples would be necessary, based on a stratified sample taking into consideration two types of gillnet fleet (coastal and offshore) and more longliners' fishing trips.

Over-quota discards were rare. Most of the time, the crews of these coastal vessels misinterpreted an obligation to discard related to quota (food waste or loss of earnings). Discards of undersize individuals affected a small part of fish caught $(2 \%)$, and this aspect seems not to be included in the fishermen's strategy. On the scale of the whole Bay of Biscay, discards of undersize individuals represented larger proportions of the total discards, a difference that can, for trammel netters and longliners, be partly due to catches of whiting (Merlangius merlangus) affected by the regulation CE 850/98. Discards of protected species were also very low in those fisheries (less than 
$1 \%$ ) for both the Southern Bay of Biscay and the whole Bay of Biscay, and were seen as a twist of fate or bad luck.

More generally, during the trips, changes in strategies related to regulatory issues (quota, size and protected species) were not observed. However, discussions with fishermen on board highlighted the existence of fishermen's behaviors and adaptations in order to prevent unwanted species or sizes being caught, thus avoiding discarding them. A change of fishing area was observed during one fishing trip on board a netter vessel to avoid catches of non-commercial crabs (Polybius henslowii and Liocarcinus holsatus). Another fisherman explained that in springtime, during the mass arrival of mackerel in the area for reproduction [32], sometimes he preferred to stop his activity for a few days to avoid major discards of mackerel, "because it is not doing the job well". Furthermore, a lack of resources, the discarding-conducive periods or low fish price season often determine the periods for technical shutdown chosen by some ship owners.

Beyond likely ethical considerations, in both cases the motivation behind these strategic changes is the desire to reduce workload, "to prevent the day's drudgery". The issue of workload is significant; the crews of observed netters often suggested that the fishing strategy also depended on this factor (or cost) and not only on expected gains: the sorting of fish that will be discarded is perceived as a waste of time and an additional task. In contrast, working on fish that will be landed and sold is considered a job of higher value. For the crews, the question then is: what is acceptable in terms of the level of discarded quantity and the amount of bad or unpaid labor? In this regard Pascoe [6] explained that it is difficult to assess the cost of sorting discarded species when crews are remunerated with a system of sharing, as seen on those vessels, and not by worked hours, as in industry, for example. Here, sorting is part of the job. The observation method did not find the limits (discard quantity with additional work) that induce change of area or gears, for example. This would require several trips consecutively on the same boat, because generally a netter fishing operation lasts about 23 hours, versus three or four hours for longliners only once a day, while it is also three or four hours for the trawlers with several fishing operations per day. For longliners, the discarded individuals represent less additional workload; strategic changes (carried out the next day) are mainly related to the yields of species landed and their prices; but their room for maneuver is also limited by the presence of other longliners in this area. On board trawlers, it is known that several consecutive unprofitable hauls (with sometimes a very large share of discarding) can induce an immediate change of area. In integrating some economic parameters (such as costs and income of the trip, the fishermen's share in the catch) during observations at sea, it should be possible to estimate the limits which induce strategic changes. Furthermore, the hauls targeting high value species, despite many discards, could be assessed in the same way.

The fishermen have an economic interest in reducing the soak time of fishing gear, in decreasing degradation of the catch quality by scavengers and predators, common on passive fishing gears, and in maintaining good quality. To decrease degradation due to amphipods, all fishermen explained that they avoid the "infested areas" when they set the fishing gears. It was also noted by Santos et al [43] that, in the case of gillnets in Southern Portugal, a long soak time increased quality-related discards of hake. During a trip on a netter (Southern Bay of Biscay), two abnormal operations due to net hauling failure the day before generated $41 \%$ discards in weight, with $65 \%$ in relation to the quality criteria, thus confirming Santos' observations. In the case of French trawlers operating in the Celtic Sea, Rochet and Trenkel [17] demonstrated a positive relationship between fishing time and discards that also depends on species (some of them being more fragile). However, this pattern could not be established for passive gears on the scale of the whole Bay of Biscay.

In some cases, fish and also crabs that are usually discarded were kept for the bait of other vessels, which can favor social cohesion in ports. 
Management measures to reduce discarding have generally focused on technical solutions such as closed areas, temporary closures and mesh size increase or selective devices. Sometimes the implementation of such technical measures has displaced the discarding, moving it to other species or areas, or created new problems like increased market demand for small fish [14]. However, coupled with other strategies, these technical measures are often relevant, despite their mitigated success, their acceptance and the low incentives to adopt them [44]. Nevertheless, Garcia et al [45] reported that mesh size regulations are often inconsistent in maintaining biodiversity and fish yield, and also suggested that a balanced harvesting approach, taking into account discards "just seen as nuisance" as well as all ecosystem components, could improve fisheries management. The discard ban aims to change behavior in particular with the use of more selective gears to decrease discards up to a regulated level and increase stock health; thus, Northeast Arctic discard bans and fishermen's compliance helped to improve fishing stocks [2]. In the case of multi-species fisheries targeting some under-quota species, it is not certain that discard bans would promote any reduction of fishing effort and increase stock health. It could also mean that these catches are landed for other uses such as producing fertilizer or fish meal, with the risk of creating an incentive to target "discarded" individuals, even if a large part of landed individuals are already used in feed production for aquaculture and livestock industries (about $30 \mathrm{Mt}$, nearly one third of global landings and about $2 \%$ of the fish meal is composed of wild species) [46]; a ban could also mean the beginning of a new vicious circle.

\section{Conclusion}

The observation method described here has been shown to be efficient in understanding, qualifying and quantifying the reasons for discarding. The method is easy to implement with two observers on board, but criteria of discards could be simplified in quality, regulation and market reasons in order to be workable by only one observer. The observations at sea highlighted the significant proportion of discards in the case of passive gears and the preponderance of market quality reasons for discarding in the case of netters and longliners. For the latter, it should be noted that a large part of discards were alive, however it is not an indication of their long term survival. Regulations were responsible for a small part of discarding. It is possible that a specific commercial action (e.g. promotion, transformation), might encourage better economic value of today's discarded species and could decrease discards. In this regard and in this area, grey triggerfish (Balistes carolinensis) were usually discarded. Now transformed into fresh fish fillet before being sold, they are discarded less and less frequently. However, it is well known that dietary habits of consumers are difficult to change [47], so a significant reduction of discards related to market conditions should not be expected, all the more so because, currently, a part of the landed catch is not highly valued, and is even destroyed [9].

According to Hall and Mainprize [2], the fisheries management toolbox is complete and diversified but the effectiveness of the different tools used to settle the issue of discards mainly depends on the understanding and involvement of the main stakeholders: the fishermen, all together.

On the scale of the Bay of Biscay, within the framework of the French observer program, the assessment at sea of discarding shows significant regional differences and also differences related to different practiced métiers [40]. The observations undertaken in the LOUPE program likewise show a large variability of discarding between métiers and within each métier, between fishing operations. These considerations and also seasonal variations make it difficult to model and extrapolate; this would require more observations. The assessment further emphasizes that the introduction of European regulations on discards should take into account the diversity of discarding patterns and discarding reasons for optimal efficiency, and that the reduction of discards could be implemented efficiently by using case-by-case solutions. 


\section{Acknowledgements}

This work was done in the context of the LOUPE research project. Thanks to financial support from the Conseil Général des Landes, the Conseil Général des Pyrénées Atlantiques, the Aquitaine Region, the French State (DIRM SA), EU funds (EFF), the regional fishing committee CRPMEM Aquitaine and the local fishing committee CIDPMEM Pyrénées Atlantiques Landes. Laurence Fauconnet received a $\mathrm{PhD}$ fellowship from the Région Pays de la Loire. Support was also provided by the French Department for Ecology, Sustainable Development and Energy (Direction des Pêches Maritimes et de l'Aquaculture). We also thank the fishermen, in particular those of St Jean de Luz and Capbreton, for their help on board and their interest in our research projects.

\section{References}

[1] Anonyme 2002. Rapport du Sommet mondial pour le développement durable, 2002; A/CONF.199/20.

[2] Kelleher K. Discards in the world's marine fisheries. An update, Fisheries Technical Paper. FAO $n^{\circ} 470 ; 2005$.

[3] Hall SJ and Mainprize BM. Managing by-catch and discards: how much progress are making and how can we do better? Fish and Fisheries 2005; 6:134-155.

[4] Diamond B and Beukers-Stewart B. Fisheries discards in the North Sea: Waste of resources or a necessary evil? Fisheries Science 2011; 19(3):231-245.

[5] Alverson DL, Freeberg MH, Murawski SA, Pope JG. A global assessment of fisheries bycatch and discards. Fisheries Technical Paper FAO n 339, 1994.

[6] Pascoe S. Bycatch management and economics of discarding. Fisheries Technical Paper FAO $\mathrm{n}^{\circ} 370 ; 1997$.

[7] Boncoeur J, Fifas S., Gallic BL. Un modèle bioéconomique d'évaluation du coût social des rejets au sein d'une pêcherie complexe. Economie et Prévision 2000; 143-144, 185-199.

[8] Walters C, Martell SJD, Christensen V, Mahmoudi B. An ECOSIM model for exploring gulf of Mexico ecosystem management options: implications of including multistanza life-history models for policy predictions. Bulletin of Marine Science 2008; 83, 251-271.

[9] Gustavsson J, Cederberg C, Sonesson U, Van Otterdijk R, Meybeck A. Global food losses and food waste. Study conducted for the International Congress SAVE FOOD, FAO 2011.

[10] Macher C, Guyader O, Talidec C, Bertignac M. A cost-benefit analysis of improving trawl selectivity in the case of discards: the Nephrops norvegicus fishery in the Bay of Biscay. Fisheries Research 2008; 92:76-89.

[11] Catchpole TL, Frid CLJ, Gray TS. Discards in North Sea fisheries: causes, consequences and solutions. Marine Policy 2005; 29:421-430.

[12] Ramsay K, Kaiser MJ, Moore PG, Hughes RN. Consumption of fisheries discards by benthic scavengers: utilization of energy subsidies in different marine habitats. Journal of Animal Ecology 1997; 66:884-896.

[13] Groenewold S and Fonds M. Effect on benthic scavengers of discards and damaged benthos produced by beam-trawl fishery in southern North Sea. ICES Journal of Marine Science 2000; 57:1395-1406.

[14] Zador S G and Fitzgerald SM. Seabird attraction to trawler discards. Alaska Fisheries Science Center, AFSC Processed Rep. 2008-06; 2008.

[15] Blaber SJM and Wassenberg TJ. Feeding ecology of the piscivorous birds Phalacrocorax varius, P. melanoleucos and Sterna bergii in Moreton Bay, Australia: diets and dependence on trawler discards. Marine Biology 1989; 101:1-10.

[16] Berghan R and Rosner HU. A method to quantify feeding of seabirds on discard from the shrimp fishery in the North Sea. Netherlands Journal of Sea Research 1992; 28(4):347-350.

[17] Rochet MJ and Trenkel V. Factors for the variability of discards: assumptions and field evidence. Canadian Journal of fisheries and Aquatic Sciences 2005; 62:224-235. 
[18] Madsen N, Holst R, Foldager L. Escape windows to improve the size selectivity in the Baltic cod trawl fishery. Fisheries Research 2002; 57:223-235.

[19] Machias A, Maiorano P, Vassilopoulou V, Papaconstantinou C, Tursi A, Tsimenides N. Sizes of discarded commercial species in the eastern-central Mediterranean Sea. Fisheries Research 2003; 66:213-222.

[20] Pranovi F, Raicevich S, Franceschini G, Torricelli P, Giovanardi O. Discard analysis and damage to non-target species in the "rapido" trawl fishery. Marine Biology 2001; 139:863-875.

[21] Casey J. Estimating Discards Using Selectivity Data: the effects of including discard data in assessments of the demersal fisheries in the Irish Sea. Journal Northwest Atlantic Fishery Science 1996; 19:91-102.

[22] Fernandez C, Cervino S, Perez N, Jardim E. Stock assessment and projections incorporating discard estimates in some years: an application to the hake stock in ICES Divisions VIIIc and IXa. ICES Journal of Marine Science 2010; 67:1185-1197.

[23] Lart WJ. Discard studies, engaging fishers in support of management. ICES CM 2002; V:29.

[24] Arnason R. On catch discarding in fisheries. Marine Resource Economics 1994; 9:189-207.

[25] Arnason R. On selectivity and discarding in an ITQ fishery, proceeding of the Fifth European. Association of Fisheries Economists' Bioeconomic Modelling Workshop, Edinburgh, 1995; p. 13.

[26] Anderson LG. An economic analysis of high grading in ITQ fisheries regulation programs. Marine Resource Economics 1994; 9:209-226.

[27] Boyce JR. An economic analysis of the fisheries bycatch problem. Journal of Environmental Economics and Management 1996; 31:314-336.

[28] Branch TA, Rutherford K, Hilborn R. Replacing trip limits with individual transferable quotas: implications for discarding. Marine Policy 2006; 30:281-292.

[29] Sampson DB. Fishing tactics in a two species fisheries model: the bioeconomics of bycatch and discarding. Canadian Journal of Fisheries and Aquatic Science 1994; 51(12):2688-2694.

[30] Vestergaard N. Discard behaviour, highgrading and regulation: the case of the Greenland shrimp fishery. Marine Resource Economics 1996; 11:247-266.

[31] Le Pape O, Chauvet F, Desaunay Y, Guérault D. Relationship between interannual variations of the river plume and the extent of nursery grounds for the common sole (Solea solea, L.) in Vilaine Bay. Effects on recruitment variability. Journal of Sea Research 2003; 50:177-185.

[32] Borja A, Uriarte A, Egaña J. Environmental factors and recruitment of mackerel, Scomber scombrus L. 1758, along the north-east Atlantic coasts of Europe. Fisheries Oceanography 2002; 11:1-12.

[33] Borja A, Uriarte A, Egaña J, Motos L, Valencia V. Relationships between anchovy (Engraulis encrasicolus) recruitment and environment in the Bay of Biscay (1967-1996). Fisheries Oceanography 1998; 7:375-380.

[34] Sourget Q and Biais G. Ecologie, biologie et exploitation du maigre du golfe de Gascogne. IFREMER/CNRS report; 2009.

[35] Sánchez F and Gil G. Hydrographic mesoscale structures and poleward current as a determinant of hake (Merluccius merluccius) recruitment in southern Bay of Biscay. ICES Journal of Marine Science 2000; 57:152-170. 
[36] Leblond E, Daurès F, Merrien C, Demaneche S, Le Blond S, Berthou P. Activité 2010, des navires de pêche de la région Aquitaine. Ifremer SIH; 2013.

[37] Sanchez F, Morandeau G, Bru N, Lissardy M. A restricted fishing area as a tool for fisheries management: Example of the Capbreton canyon, southern Bay of Biscay. Marine Policy 2013; 42:180-189.

[38] Leblond E, Daurès F, Merrien C, Demaneche S, Le Blond S, Berthou P. Synthèse des flottilles de pêche 2010.Flotte de la façade Atlantique. Ifremer SIH; 2012.

[39] Leblond E, Daurès F, Berthou P, Dintheer C. The Fisheries Information System of Ifremer: a multidisciplinary monitoring network and an integrated approach for the assessment of French fisheries, including small-scale fisheries. ICES CM 2008/K: 11; 2008.

[40] Dubé B, Dimeet J, Rochet MJ, Tétard A, Gaudou O, Messannot C, Fauconnet L, Morizur Y, Biseau A, Salaun M. Observations à bord des navires de pêche professionnelle. Bilan de l'échantillonnage 2011, RBE/STH/LTBH 008; 2012.

[41] Erzini K, Gonçalves JMS, Bentes L, Lino PG, Ribeiro J. The hake deepwater semi-pelagic ("pedra-bola") longline fishery in the Algarve (southern Portugal). Fisheries Research 2001; 51:327-336.

[42] Benoît HP and Allard J. Can the data from at-sea observer surveys be used to make general inferences about catch composition and discards? Canadian Journal of fisheries and Aquatic Sciences 2009; 66:2025-2039.

[43] Santos MN, Gaspar MB, Monteiro CC, Vasconcelos P. Gillnet and long-line catch comparisons in a hake fishery: the case of southern Portugal. Scientia Marina 2002; 66(4):433-441.

[44] Suuronen P and Sardà F. The role of technical measures in the European fisheries management and how to make them work better. ICES Journal Marine Science 2007; 64 (4):751-756.

[45] Garcia SM, Kolding J, Rice J, Rochet MJ, Zhou S, Arimoto T, Beyer JE, Borges L, Bundy A, Dunn D, Fulton EA, Hall M, Heino M, Law R, Makino M, Rijnsdorp D, Simard F, Smith ADM. Reconsidering the consequences of selective fisheries. Science 2012, Vol. 335 (6072):10451047.

[46] Naylor RL, Goldburg RJ, Primavera JH, Kautsky N, Beveridge MCM, Clay J, Folke K, Lubchenko J, Mooney H, Troell M. Effect of aquaculture on world fish supplies. Nature 2000; vol. 405.

[47] Lahlou S. Peut-on changer les comportements alimentaires ? Cahiers de nutrition et de diététique. The London School of Economics and Political Science 2005; 40 (2):91-96.

Appendix 1. Regulatory framework that can result discards in the southern part of the Bay of

Biscay

\begin{tabular}{ll}
\hline Denomination & Regulations \\
\hline & Ord. $n^{\circ} 2063$ (September $\left.15^{\text {th }} 1993\right)$ \\
& Reg CE n ${ }^{\circ} 57 / 2011$ \\
No quota & Reg CE n ${ }^{\circ} 43 / 2012$ \\
& Reg UE n ${ }^{\circ} 694 / 2012$ \\
& Reg UE n ${ }^{\circ} 39 / 2013$ \\
Protected species & OSPAR list ref 2008-6 (area IV) \\
& Ord. n $0171\left(J u l y ~ 26^{\text {th }} 2011\right)$ \\
Out of minimum legal size & Reg CE $n^{\circ} 850 / 98$ \\
& Reg CE n ${ }^{\circ} 1559 / 2007$ \\
\hline
\end{tabular}

